\title{
Quarry Dust Based Cement Mortar with Inclusion of Bacteria A Waste Utilization Approach for Next Generation
}

\author{
Fenal Patel ${ }^{1}$, Prof. (Mrs.) Reshma L. Patel ${ }^{2}$, Dr. Jayesh kumar Pitroda ${ }^{3}$ \\ ${ }^{1}$ Finalyear M. Tech. Student, Environmental Engineering, B.V.M. Engineering College, V.V. Nagar, \\ Gujarat, India \\ ${ }^{2}$ Associate Professor, Civil Engineering Department, B.V.M. Engineering College, V.V. Nagar, \\ Gujarat, India \\ ${ }^{3}$ Assistant Professor, Civil Engineering Department, B.V.M. Engineering College, V.V. Nagar, \\ Gujarat, India
}

\begin{abstract}
In the fast developing era urbanization takes place very rapidly and it is directly or in directly harmful for environment. Most common construction material cement mortar contains sand which is natural resource and as demand of sand (fine aggregate) increases scarcity of natural sand is the main concern. On the other hand aggregate crushing plant has a byproduct "Quarry Dust". Replacement of quarry dust by natural sand in cement mortar is done after comparing physical and chemical properties of natural sand and quarry dust. The results shows that it has almost similar properties so in this research natural sand is $100 \%$ replaced by quarry dust and in addition inclusion of bacteria (Bacillus Pesteurii) in different concentration like; $10^{5}$, $10^{6}, 10^{7}, 10^{8} \mathrm{cell} / \mathrm{ml}$ is done. As Bacillus Pesteurii can produce calcium carbonate $\left(\mathrm{CaCO}_{3}\right)$ as a filler material and serve as a binding factor in cement mortar. This study shows that the compressive strength is increases of the bacterial mortar than the standard mortar or sustainable mortar. The results of compressive strength test are higher of the cell concentration $10^{7} \mathrm{cell} / \mathrm{ml}$ that is $31.01 \mathrm{~N} / \mathrm{mm}^{2}$. So a sustainable cement mortar which is economical can be used to utilize waste and protection of environment can be done.
\end{abstract}

Keywords: Cement Mortar, Quarry Dust, Waste Utilization, Bacterial Mortar, Environment

\section{INTRODUCTION}

This study has a concept of quarry dust based cement mortar with the inclusion of bacteria. Quarry dust can be defined as residue, tailing or other non-voluble waste material after the extraction and processing of rocks to form fine particles less than $4.75 \mathrm{~mm}$. Usually, quarry dust is used as a surface filler material in highway constructions. Quarry dust is abundantly available to the extent of 200 million tons per annum which has a landfill disposal problems and environmental hazards. In present study replacement of sand by quarry dust is an attempt to utilize waste and reduce the use of natural sand. As this is an attempt to use sustainable and economical cement mortar for the fast developing infrastructures.

In addition, by using new invention of bacterial mortar bacteria (Bacillus Pesteurii) added to have better strength results. Bacterial mortar is a science of precipitation of calcite carbonate $\left(\mathrm{CaCO}_{3}\right)$ and it has ability to heal the cracks of cement mortar. So this study introduces a new sustainable cement mortar which is more durable than standard cement mortar.

\section{Experimental Materials}

Following are the experimental materials for the research experimental work.

\subsection{Quarry Dust}

The Quarry Dust was taken from the Sahjan and Quarry Works, Sevaliya, Gujarat state, India. Quarry Dust is collected from its disposal site on the Quarry site. The quarry dust is in a powdered form having the size less than $4.75 \mathrm{~mm}$. Quarry Dust was tested for checking the physical and chemical properties. The Figure 1 shows Quarry Dust. 


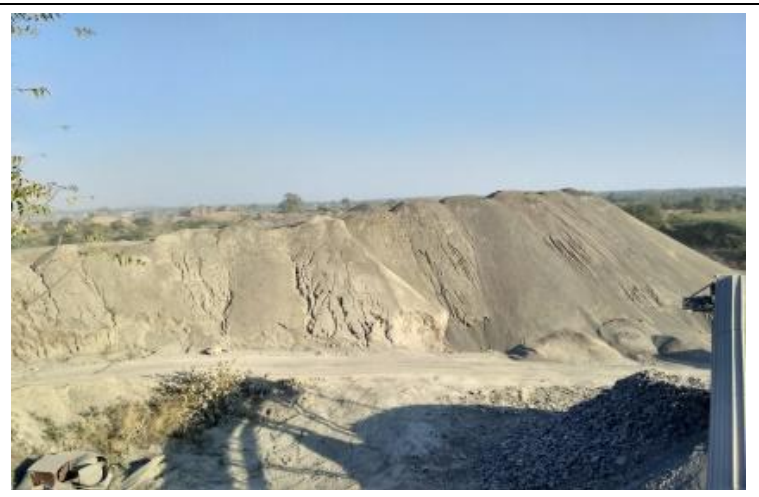

Figure1. Quarry Dust

Quarry dust has almost similar properties of Fine aggregate (natural sand). The comparison of natural sand and quarry dust properties (physical and chemical) is shown in Table 1 and 2.

Table1. Physical Requirement of Quarry Dust and Fine aggregate (Natural Sand)

\begin{tabular}{|c|c|c|c|}
\hline Property & Quarry dust & $\begin{array}{l}\text { Fine aggregate } \\
\text { (Natural sand) }\end{array}$ & Test method \\
\hline Specific gravity & $2.54-2.60$ & 2.60 & IS2386(Part III)- 1963 \\
\hline Bulk density $\left(\mathrm{kg} / \mathrm{m}^{3}\right)$ & $1720-1810$ & 1460 & IS2386(Part III)- 1963 \\
\hline Absorption (\%) & $1.20-1.50$ & Nil & IS2386(Part III)- 1963 \\
\hline Moisture Content (\%) & Nil & 1.50 & IS2386(Part III)- 1963 \\
\hline Sieve analysis & Zone-II & Zone-II & IS $383-1970$ \\
\hline
\end{tabular}

Table2.Chemical Requirement of Quarry Dustand Fine aggregate(Natural Sand)

\begin{tabular}{|l|c|c|}
\hline \multicolumn{1}{|c|}{ Compounds } & Quarry dust (\% by weight) & $\begin{array}{c}\text { Fine aggregate(Natural sand) } \\
\text { (\% by weight) }\end{array}$ \\
\hline Lime & 3.28 & 02.93 \\
\hline Silica & 64.84 & 88.25 \\
\hline Alumina & 0.12 & 00.71 \\
\hline Iron Oxide & 0.94 & 00.93 \\
\hline Potassium Oxide & 00.07 & 00.30 \\
\hline Sodium Oxide & 00.15 & 00.01 \\
\hline Sulphite & 00.22 & 00.08 \\
\hline Magnesia & 8.49 & 00.17 \\
\hline
\end{tabular}

\subsection{Fine Aggregate}

Fine aggregate is a naturally occurring granular material composed of finely divided rock and mineral particles. Those fractions from $4.75 \mathrm{~mm}$ to 150 microns are termed as fine aggregate. The Figure 2 shows fine aggregate.

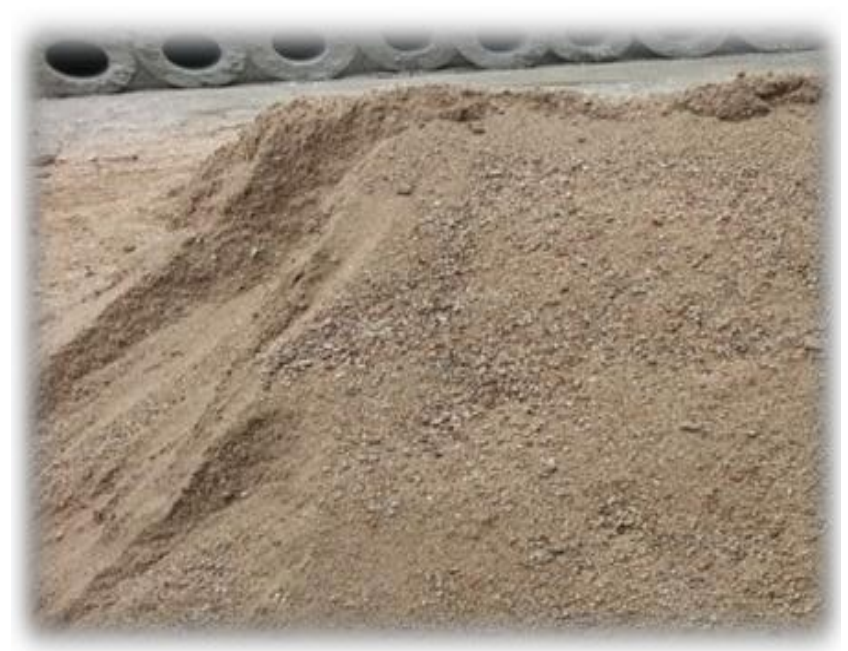

Figure2. Fine Aggregate

(Source: Galaxy India Pvt ltd.) 


\subsection{Bacteria}

Bacillus species are aerobic, sporulating, rod-shaped bacteria that are ubiquitous in nature. Majority of Bacillus species are harmless. Bacillus is a type of bacteria that can produce calcium carbonate $\left(\mathrm{CaCO}_{3}\right)$ as a filler material and serve as a binding factor in cement mortar. Calcium carbonate $\left(\mathrm{CaCO}_{3}\right)$ can reduce capillarypores of concrete and improve durability and compressive strength. The Figure 3 shows Bacillus Pesteurii NCIM 2477.

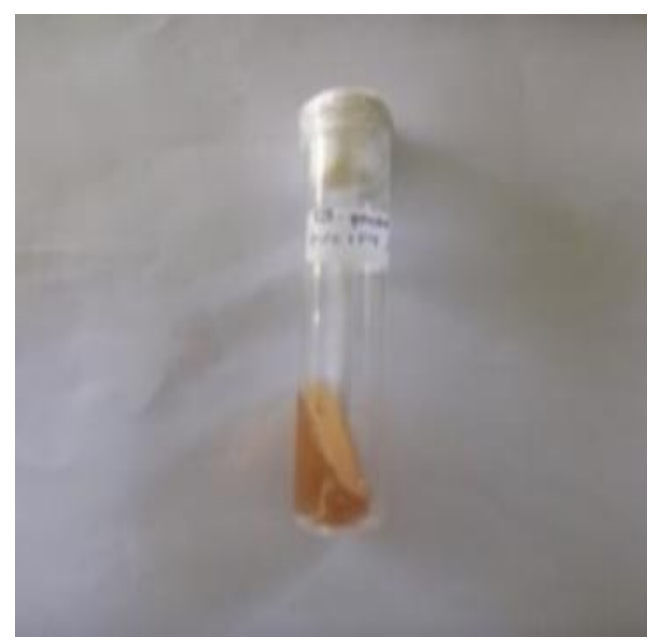

Figure3. Bacillus Pesteurii NCIM 2477

(Source: ARIBAZ laboratory New Vallabh Vidyanagar)

\subsection{Cement}

The cement utilized for the present examination was Ordinary Portland Cement (OPC) Grade-53 (Hibond 53). It is conformed to the requirement of Indian Standard specification BIS 12269 - 1987. Figure 4 shows Hi-bond 53 Grade Ordinary Portland Cement.

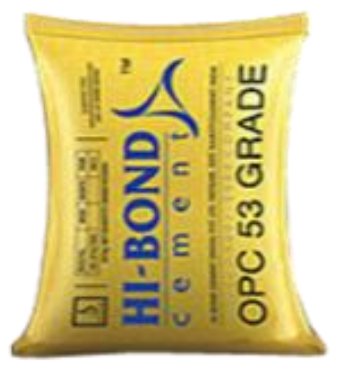

Figure4. Hi-bond 53 Grade $O P C$

\section{DESIGN MiX}

Design Mix of Cement Mortar as shown in table 3.Material required for casting of cubes: (for 1 cube size $70.7 \mathrm{~mm} \times 70.7 \mathrm{~mm} \times 70.7 \mathrm{~mm}$ )

Table3. Design Mix of Cement Mortar

\begin{tabular}{|c|c|c|c|}
\hline Materials & Cement & Natural Sand / Quarry dust & Water \\
\hline Weight & $190 \mathrm{gm}$. & $640 \mathrm{gm}$. & $90 \mathrm{ml}$ \\
\hline
\end{tabular}

\section{EXPERIMENTAL MeTHOdOLOGY}

\subsection{Compressive Strength Test}

Procedure for casting: take the sand and cement as per required weight mix thoroughly on the nonporous surface until it gets mix well. Now add water and mix until its get uniform color. In bacterial mortar bacteria of different concentration is added into the distilled water and that water is added into the sand cement mixture. This paste is poured into the mortar mould and vibrated for 2 minute for the compaction. After 24 hours demould that mortar cube after it gets harden and cure that cube into a clear water for 28 days. 

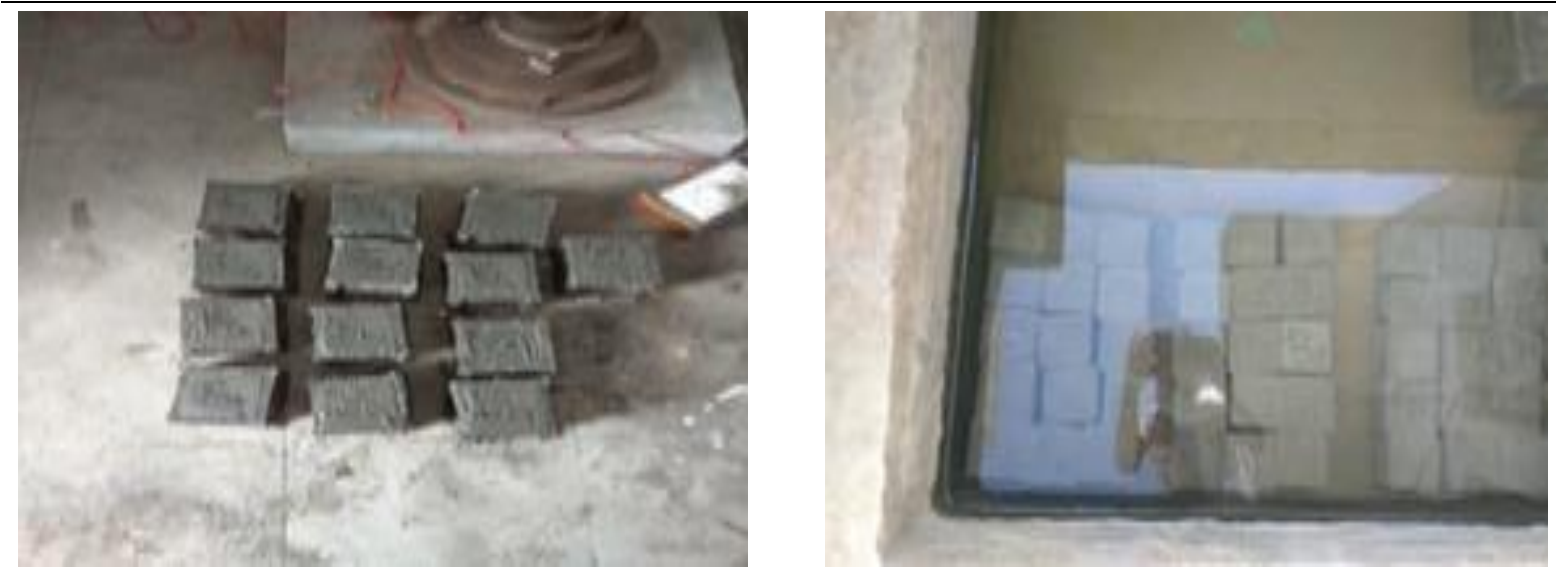

Figure5. Casting and curing of cement mortar cube

(Source: Sadbhav consultancy at nana bazar, Vallabh Vidyanagar)

Testing Methodology for compressive strength test after 7 days, 14 days, 28 days cubes were taken out and tested under compression testing machine. The results of the compression tests at $7,14,28$ days are given in Table4 and Figure6.

Table4.Comparative Experimental Results for Compressive Strength Test for all Mixes in Cement Mortar at 7 , 14 and 28 Days

\begin{tabular}{|c|c|c|c|c|}
\hline \multirow[t]{2}{*}{ Description } & \multirow[t]{2}{*}{ Cement Mortar Mixes } & \multicolumn{3}{|c|}{ Average Compressive Strength $\left(\mathrm{N} / \mathrm{mm}^{2}\right)$} \\
\hline & & 7 days & 14 days & 28 days \\
\hline $\begin{array}{c}\text { Fine Aggregate (Natural } \\
\text { Sand) based }\end{array}$ & A & 8.14 & 10.80 & 17.87 \\
\hline Quarry Dust based & $\mathbf{B}$ & 11.00 & 12.40 & 17.87 \\
\hline \multirow{4}{*}{$\begin{array}{c}\text { Quarry Dust +Bacteria } \\
\text { based } \\
\text { (Bacillus Pesteurii) }\end{array}$} & B1 $\left(10^{5}\right.$ cells/ml $)$ & 12.00 & 14.27 & 24.41 \\
\hline & B2(10 6 cells/ml $)$ & 20.27 & 23.54 & 28.81 \\
\hline & B3 $\left(10^{7}\right.$ cells $\left./ \mathrm{ml}\right)$ & 22.81 & 24.14 & 31.01 \\
\hline & B4 $\left(10^{8}\right.$ cells $\left./ \mathrm{ml}\right)$ & 19.34 & 22.27 & 23.54 \\
\hline
\end{tabular}

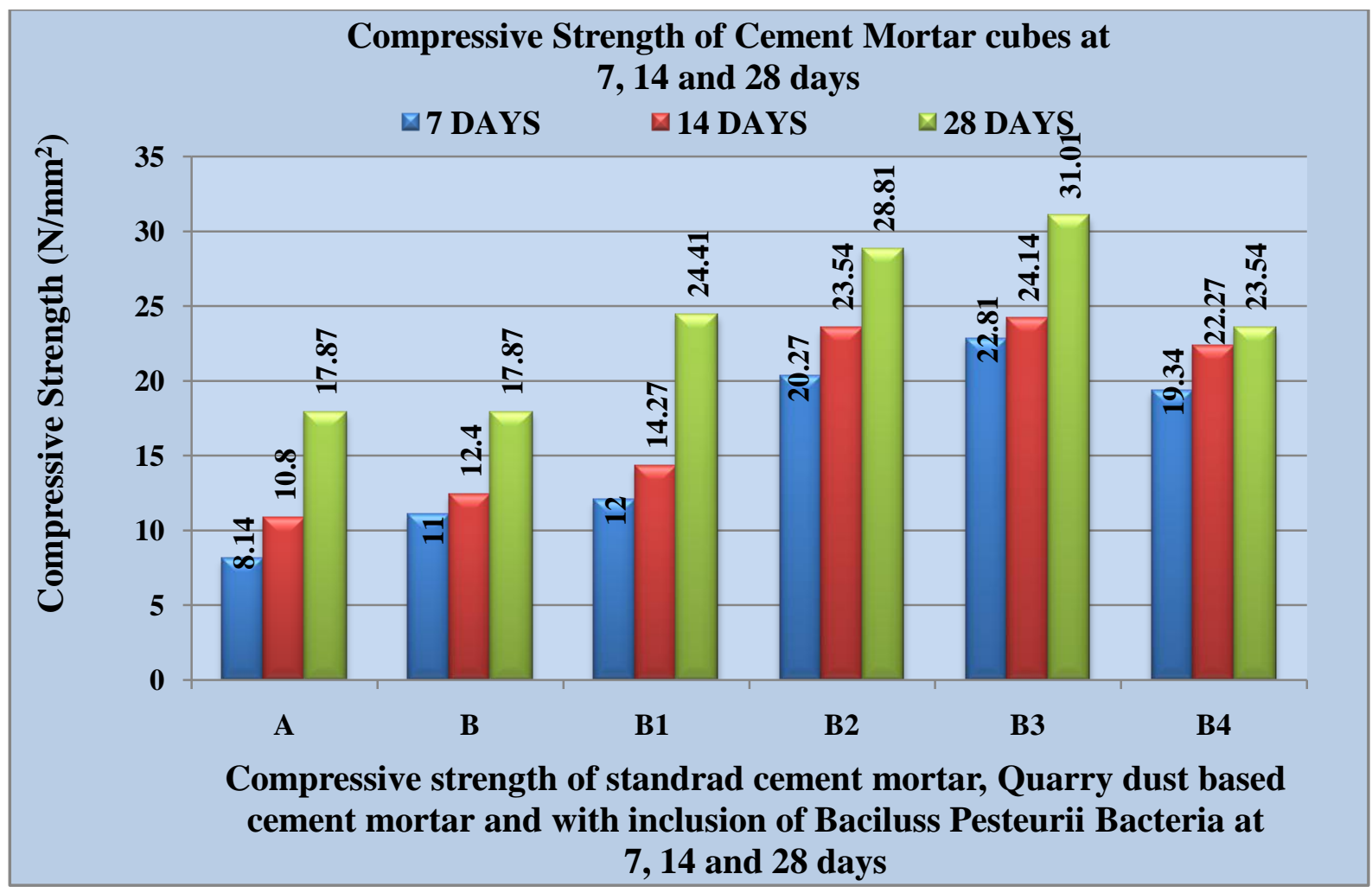

Figure6. Compressive Strength Test

From above figure 6, it can be said that compressive strength of cement mortar is increasing as the 

Generation

concentration of bacteria is increasing but decreases at the cell concentration $10^{8} \mathrm{cells} / \mathrm{ml}$ (B4). So comparing the standard cement mortar strength with quarry dust based mortar it gives higher strength but the highest strength is achieved at B3 $\left(10^{6}\right.$ cells $\left./ \mathrm{ml}\right)$ bacterial concentration that is $31.01 \mathrm{~N} / \mathrm{mm}^{2}$ at 28 days.

\subsection{Water Absorption Test}

For water absorption, after curing for 28 days put the cubes into oven at $85^{\circ} \mathrm{c}$ temperature for 24 hours drying. Weight the dried cubes and again put it in the water for 24 hours. Next day take the wet weight of the cubes. The results of the Water Absorption Test at 28 days are given in Table 5 and Figure7.

Table5. Average Water Absorption Test Results for all Cement Mortar Mixes at 28 Days

\begin{tabular}{|c|c|c|}
\hline Description & Cement Mortar Mixes & $\begin{array}{c}\text { Average Water Absorption (\%) at } \\
\text { 28 days }\end{array}$ \\
\hline $\begin{array}{c}\text { Fine Aggregate } \\
\text { (Natural Sand) based }\end{array}$ & $\mathbf{A}$ & 0.84 \\
\hline Quarry Dust based & $\mathbf{B}$ & 1.40 \\
\hline $\begin{array}{c}\text { Quarry Dust + Bacteria based } \\
\text { (Bacillus Pesteurii) }\end{array}$ & $\mathbf{B 1}(\mathbf{1 0}$ cells/ml) & 2.14 \\
\cline { 2 - 3 } & $\mathbf{B 2}(\mathbf{1 0}$ cells/ml) & 1.45 \\
\cline { 2 - 3 } & $\mathbf{B 3}\left(\mathbf{1 0}^{\mathbf{7}}\right.$ cells/ml) & 1.26 \\
\cline { 2 - 3 } & $\mathbf{B 4}(\mathbf{1 0}$ cells/ml) & 1.65 \\
\hline
\end{tabular}

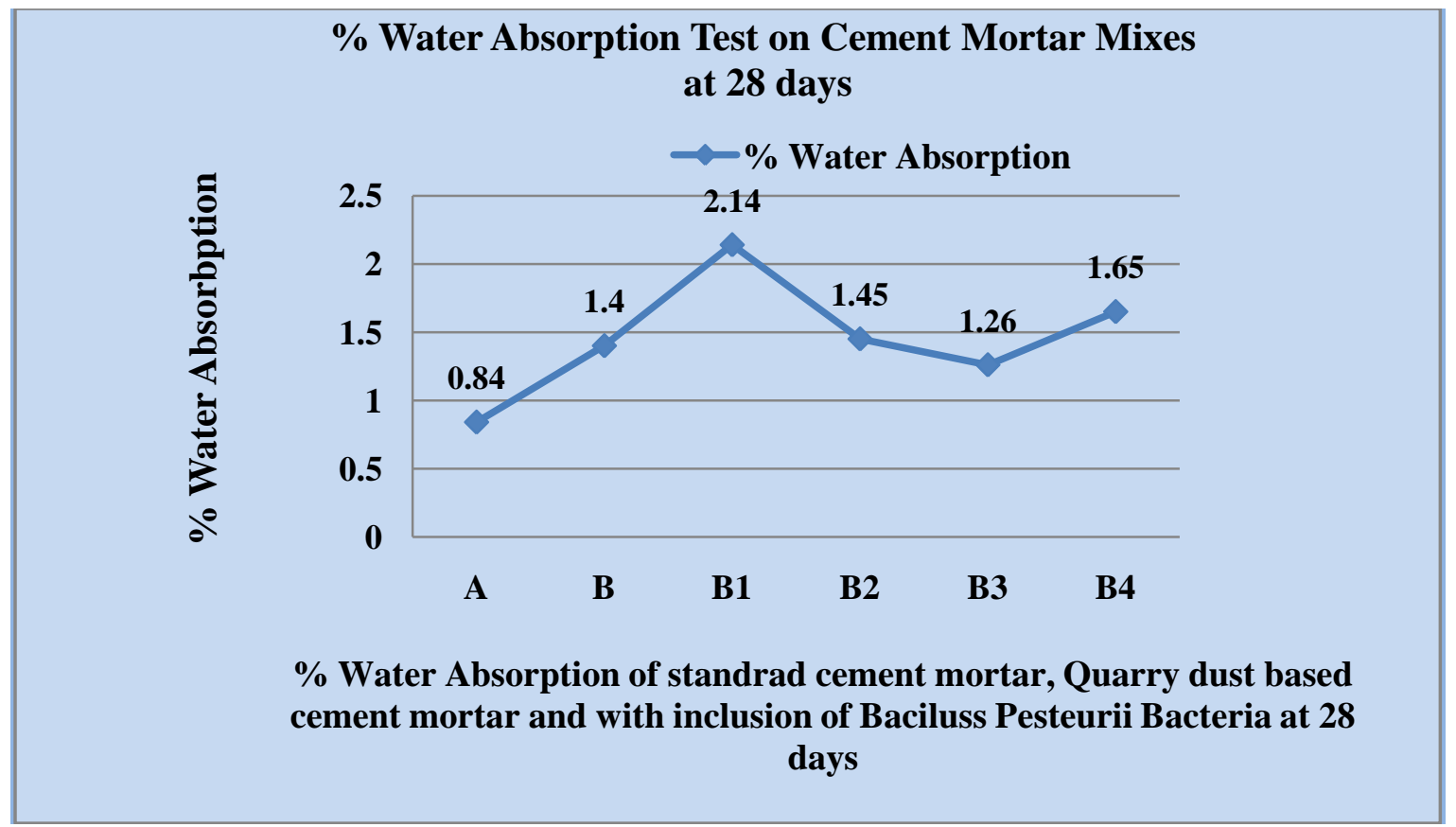

Figure7. Water Absorption Test

From the above figure 7 , it can be said that water absorption is quite high compare to standard mortar but is lesser at B3 $\left(10^{7}\right.$ cells $\left./ \mathrm{ml}\right)$ concentration that is 1.26 .

\section{Conclusions}

From this study following conclusion can be drawn:

a) The compressive strength of bacteria mortar is higher than standard mortar cubes so bacterial mortar is a sustainable, economical and more durable.

b) The water absorption is lesser where the compressive strength is higher.

c) It can be concluded that the B3 type of mortar is a new invention as it is quarry dust based bacterial mortar and having a highest compressive strength $31.01 \mathrm{~N} / \mathrm{mm}^{2}$ and water Absorption is 1.26 . 


\section{ACKNOWLEDGEMENT}

The Authors thankfully acknowledge to Dr. C. L. Patel, Chairman, CharutarVidyaMandal, and Er. V. M. Patel, Hon. Jt. Secretary, Charutar Vidya Mandal, Prof. (Dr.) Indrajit Patel, Principal, B.V.M. Engineering College, Vallabh Vidyanagar, Gujarat, India for their motivations and infrastructural support to carry out this research.

\section{REFERENCES}

[1] Ashish B.Ghogare, P.P. Saklecha, M.R.Nikhar. (2016), "Comparative Parameter of Stone Dust as a Replacement Material of Sand" International Journal for Research in Applied Science \& Engineering Technology (IJRASET)Volume 4 Issue VI, ISSN: 2321-9653.

[2] Akshay C. Sankh, Praveen M. Biradar, Prof. S. J Naghathan, Manjunath B. Ishwargo, (2012), "Recent Trends in Replacement of Natural Sand with Different Alternatives", IOSR Journal of Mechanical and Civil Engineering (IOSR-JMCE) ISSN: 2278-1684, P.P.- 59-66.

[3] Fenal Patel, Prof. (Mrs) Reshma L. Patel, Dr. Jayesh kumar Pitroda(2017), "Parametric Study on Quarry Dust and Bacteria in Cement Mortar for Next Generation: A Review", International Conference on Research and Innovations in Science, Engineering \& Technology (ICRISET 2017) Organized by Birla Vishvakarma Mahavidyalaya Engineering College (An Autonomous Institution) Managed by Charutar Vidya Mandal Vallabh Vidyanagar, Anand, Gujarat, India PP 18-22, Paper ID: ICRISET_PAPER_49, ISBN 978-93-84339-38-8 Published by: RIA Publishing House, Vallabh Vidyanagar, $17^{\text {th }}-19^{\text {th }}$ February 2017

[4] Hanumanth Rao M., Viswanadh G.(2015)"Experimental Study on Bacterial Cement Composites" International Journal of Computer Engineering In Research Trends ,Volume 2, ISSN (O): 2349-7084 p.p.- 953-958.

[5] Kim Van Tittelboom, Nele De Belie, Willem De Muynck, Willy Verstraete. (2010), "Use of bacteriato repair cracks in concrete", Cement and Concrete Research40 p.p.-157-166.

[6] Maheswaran S.,Dasuru S. S.RamaChandra A.Murthy, Bhuvaneshwari B.,Ramesh Kumar V., Palani G. S.,Nagesh R. Iyer, SarayuKrishnamoorthy and Sandhya S.(2014), "Strength Improvement Studies Using New TypeWild Strain Bacillus Cereuson Cement Mortar" ,Current Science, Vol. 106, NO. 1.

[7] MohaiminulHaque, Sourav Ray, H. M. A. Mahzuz.(2012) "Use of Stone Powder with Sand in Concrete and Mortar: A Waste Utilization Approach" ARPN Journal of Science and TechnologyISSN 2225-7217 VOL. 2, NO. 7.

[8] Priyanka A. Jadhav, Dilip K. Kulkarni.(2013),"Effect of replacement of natural sand by manufactured sand on the properties of cement mortar", International Journal Of Civil And Structural Engineering ISSN:0976 - 4399 Volume 3, No 3.

[9] Senthilkumar V., Palanisamy T., Vijayakumar V. N.(2014) "Comparative Studies on Strength Characteristics of Microbial Cement Mortars"International Journal of ChemTech Research Coden (USA): IJCRGG, ISSN: 0974-4290 Vol.6, No.1, p.p.- 578-590.

[10] Willem De Muynck,Dieter Debrouwer,Nele De Belie, Willy Verstraete (2008), "Bacterial carbonate precipitation improves the durability of cementitious materials", Cement and Concrete Research38,p.p-1005-1014. 

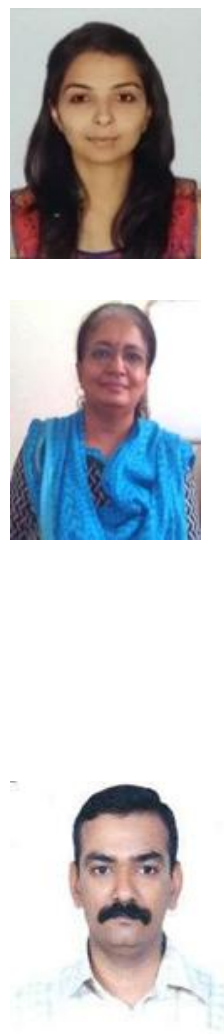

Fenal Patel received her Bachelor in Technology Degree in Civil Engineering from the Chhotubhai Gopalbhai Institute of Technology, UKA Tarsadia, in 2015. At present, she is final year student of Master's Degree in Environmental Engineering from Birla Vishvakarma Mahavidyalaya, Gujarat Technological University.

Prof. Reshma L. Patel received her Bachelor of Engineering degree in Civil Engineering from the Birla Vishvakarma Mahavidyalaya, Sardar Patel University in 1991. In 1993 she received her Master's Degree in Civil (Environmental) Engineering from Birla Vishvakarma Mahavidyalaya, Sardar Patel University. She joined Birla Vishvakarma Mahavidyalaya Engineering College as a faculty in 1994, where she is Associate Professor of Civil Engineering Department with a total experience of 22 Years in the field of Research, Designing and education. She is guiding M.E.(Environmental Engineering) Thesis work in the field of Civil/ Environmental Engineering. She has published many papers in National/ International Conferences and International Journals.

Dr. Jayesh kumar R Pitroda received his bachelor of engineering degree in Civil Engineering from Birla Vishwakarma Mahavidyalaya Engineering College, Sardar Patel University in 2000. In 2009 he received his master's degree in Construction Engineering and Management form Birla Vishwakarma Mahavidyalaya Sardar Patel University. In 2015 he received his Doctor of philosophy (Ph.D.) degree in Civil Engineering from Sardar Patel University. He joined Birla Vishwakarma Mahavidyalaya Engineering College as a faculty in 2009, where he is Assistant Professor of Civil Engineering Department with a total experience of 16 years in the field of research, designing and education. He is guiding M.E. (Construction Engineering and Management) thesis work in the field of Civil / Construction Engineering. He has published many papers in National / International Conferences and International Journals. He has published seven Research Books in the field of Civil Engineering, Rural Road Construction, National Highways Construction, Utilization of Industrial Waste, Fly Ash Bricks, Construction Engineering and Management, Eco-friendly Construction.

Citation: Dr. Jayesh kumar Pitroda (2017). Quarry Dust Based Cement Mortar with Inclusion of Bacteria A Waste Utilization Approach for Next Generation. International Journal of Constructive Research in Civil Engineering, 3(2), pp.1-33.

Copyright: (C) 2017 Dr. Jayesh kumar Pitroda et al. This is an open-access article distributed under the terms of the Creative Commons Attribution License, which permits unrestricted use, distribution, and reproduction in any medium, provided the original author and source are credited 